SHOCK TO THE SYSTEM 



\section{Shock to the System}

COUPS, ELECTIONS, AND

WAR ON THE ROAD TO

DEMOCRATIZATION

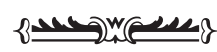

Michael K. Miller 
Copyright (C) 2021 by Princeton University Press

Princeton University Press is committed to the protection of copyright and the intellectual property our authors entrust to us. Copyright promotes the progress and integrity of knowledge. Thank you for supporting free speech and the global exchange of ideas by purchasing an authorized edition of this book. If you wish to reproduce or distribute any part of it in any form, please obtain permission.

Requests for permission to reproduce material from this work should be sent to permissions@press.princeton.edu

Published by Princeton University Press

41 William Street, Princeton, New Jersey 08540

6 Oxford Street, Woodstock, Oxfordshire OX2o 1TR

press.princeton.edu

All Rights Reserved

Library of Congress Control Number 2021936957

ISBN 978-o-691-21759-8

ISBN (pbk.) 978-o-691-21700-o

ISBN (e-book) 978-o-691-21701-7

British Library Cataloging-in-Publication Data is available

Editorial: Bridget Flannery-McCoy and Alena Chekanov

Production Editorial: Jill Harris

Cover Design: Pamela L. Schnitter

Production: Brigid Ackerman

Publicity: Kate Hensley

Cover image: Thomas Cole (1801-1848), The Course of Empire: Destruction, 1836. Oil on canvas (39 1/4 $\times 63$ 1/2 in.). Gift of the New-York Gallery of the Fine Arts, New-York Historical Society, 1858.4. Digital image: Oppenheimer Editions

This book has been composed in Miller

Printed on acid-free paper. $\infty$

Printed in the United States of America

109876654321 
For Laura and Rebecca, who I hope never need it 
